\title{
Simultaneous Second Order Derivative Spectrophotometric Determination Of Gallium (III) and Aluminium(III) using Diacetylmonoxime IsonicotinoylHydrazone
}

\author{
${ }^{1}$ P. Mallikarjuna, ${ }^{2}$ K. Sreenivasulu, ${ }^{3}$ M.V.N.V. Prasad Gupta, ${ }^{4}$ G. Thippanna, ${ }^{5}$ T. \\ Mastanaiah, ${ }^{6} \mathrm{~V}$. Suryanarayana Rao \\ ${ }^{1-6}$ Dept. of Chemistry Sri Krishnadeva University, Anantapur \\ ${ }^{I}$ Dept. of Chemistry Brindavan Institute of Technology and Science, Kurnool.
}

\begin{abstract}
Diacetylmonoxime Isonicotinoyl Hydrazone is new chromogenic reagent for the simultaneous determination of Gallium (III) and Aluminium(III). The reagent gives greenish yellow color in sodium acetateacetic acid buffer medium with the metal ions. The maximum absorbance at 377 and $367 \mathrm{~nm}$ for $\mathrm{Ga}(\mathrm{III})$ and Al(III) respectively. The molar absorptivities of Al(III) and Ga(III) are $2.69 \times 10^{4}$ and $3.17 \times 10^{4} \mathrm{L.mol}^{-1} . \mathrm{cm}^{-1}$, sandell's and sensitivities of Al(III) and Ga(III) are 0.00745 and $0.002002 \mu \mathrm{g.cm}{ }^{-2}$ respectively. A few methods are available for simultaneous determination of $G a(I I I)$ and $A l(I I I)$ by derivative spectrophotometric technique. Trace quantities of $\mathrm{Ga}(I I I)$ and $A l(I I I)$ simultaneously determined in alloys and biological samples.

Key Words:- Gallium (III), Aluminium (III), Diacetylmonoxime IsonicotinoylHydrazone, simultaneous, alloys, biological samples, computed, second order derivative spectrophotometric.
\end{abstract}

\section{Introduction}

Hydrazones are usually named after the carbonyl compounds from which they are obtained. Isonicotinoyl hydrazones are the condensations products of isonicotinic acid hydrazide and the carbonyl components. Many of physically active hydrazones find application ${ }^{1}$ in the treatment of diseases like tuberculosis, leprosy and mental disorders. Hydrazones also act as herbicides, nematocides, rodenticides, plant growth regulators, anti microbial, anti tuberculosis and anti tumor activities ${ }^{2,3}$. Hydrazones act as chelating agents by forming colored complexes with metal ions. The potential applications of hydrazones derivatives for the spectrophotometric determination of metal ions have been reviewed by Singh et.al ${ }^{4}$. The great interest towards derivative spectrophotometry is due to the increased resolution of spectral bands that means it is resolving two overlapping spectra and eliminating matrix interferences in the assay of two component mixtures using zero-crossing technique ${ }^{5,6}$. In the absence of zero-crossing point, two simultaneous equations can be solved to determine the components in such a mixture ${ }^{7,8}$. Derivative spectrophotometric analysis of twocomponent mixtures is also carried out without need to solve simultaneous equations ${ }^{9,10}$. Hydrazones reagents are widely used in our laboratories for the derivative spectrophotometric determination of metal ions ${ }^{8-11}$.

Gallium(III) and Aluminium(III) alloys are used as solid state electrolytes in fuel cells. An alloys of $\mathrm{Al}_{2} \mathrm{O}_{3}(5 \%)$ and $\mathrm{Ga}_{2} \mathrm{O}_{3}$ has high activity as a cracking catalyst for hydrocarbon oil. They also form a low melting eutectic alloy (M.P. $26.3^{\circ} \mathrm{C}$ ). Here in we report the simultaneous second order derivative spectrophotometric determination of gallium (III) and aluminium (III) using Diacetyl monoxime Isonicotinoyl Hydrazone (DAMINH) in biological samples and alloys. The proposed simultaneous method involves the use of peak-tobase line measurement technique.

\section{Materials And Methods}

\section{Apparatus}

Shimadzu 160A microcomputer based U.V - Visible spectrophotometer equipped with $1.0 \mathrm{~cm}$ quartz cells used for all absorbance studies and amplitude measurements in derivative spectrophotometery. An ELICO LI-120 digital $\mathrm{pH}$ mater was used in $\mathrm{pH}$ adjustments.

Reagents

All the reagents used were A.R grade unless and otherwise stated. All the solutions were prepared with doubly distilled water. Stock solutions $(0.01 \mathrm{M})$ of galliuml(III) and aluminium(III) were prepared by dissolving requisite quantity of gallium chloride (AR GSC) and aluminium sulphate (AR GSC) in $250 \mathrm{~mL}$ doubly distilled water respectively. The stock solutions were standardized and suitably diluted to obtain working solutions of metal ions. 


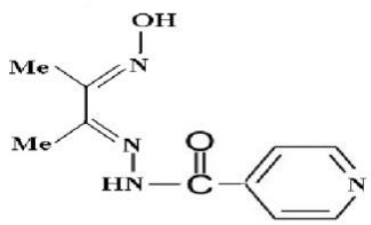

Figure 1:- Structure of Diacetyl monoxime Isonicotinoyl Hydrazone (DAMINH)

The reagent was prepared by simple condensation of Diacetylmonoxime with IsonicotinoylHydrazide in 1:1 mole ratio and its structure is given above in figure 1.The reagent solution $(0.01 \mathrm{M})$ was prepared by dissolving $0.22 \mathrm{mg}$ of compound in $100 \mathrm{~mL}$ of dimethylformamide (DMF) and the solution was found to be stable for 48 hours.

\section{Triton X-100 solution} distilled water.

A $5 \%$ solution was prepared by diluting $5.0 \mathrm{~mL}$ of Triton X-100 (AR Merk) to $100 \mathrm{~mL}$ with doubly

\section{Buffer solutions}

Buffer solutions prepared by Hydrochloric acid (1.0 M) - Sodium acetate (1.0 M) (pH 0.5 - 3.5); Acetic acid (0.2 M) - Sodium acetate (0.2 M) (pH 4.0 - 6.5); Acetic acid $(0.2 \mathrm{M})$ - Sodium acetate (1.0 M ) (pH 7.0); Sodium tetraborate decahydrate $(0.25 \mathrm{M})$ - Hydrochloric acid (0.1 M) (pH 8.0 - 9.1); Sodium tetraborate decahydrate $(0.25 \mathrm{M})$ - sodium hydroxide $(0.1 \mathrm{M})(\mathrm{pH} 9.2$ - 10.8) were used in the present study.

\section{Reaction with metal ions}

At different PH values some important metal ions were tested with DAMINH reagent. The samples were prepared in $25 \mathrm{ml}$ volumetric flasks by adding $10 \mathrm{ml}$ of buffer, $1 \mathrm{ml}$ of metal ion, $1 \mathrm{ml}$ of $0.01 \mathrm{M}$ DAMINH, $3 \mathrm{ml}$ of DMF. The reaction mixture was diluted to the mark with distilled water. The absorbance was measured in 250 - $600 \mathrm{~nm}$ range against reagent blank. The results are computed in table 1 which indicates that the reagent is potential for the spectrophotometric determination of various metal ions.

Table-1:

\begin{tabular}{|c|c|c|c|c|c|c|c|c|c|c|}
\hline \multirow{2}{*}{$\begin{array}{l}\text { Metal } \\
\text { ion }\end{array}$} & \multirow[b]{2}{*}{$\mathrm{pH}$} & \multirow[b]{2}{*}{ Color } & \multirow{2}{*}{$\begin{array}{l}2_{\max } \\
(\mathrm{nm})\end{array}$} & \multirow{2}{*}{$\begin{array}{l}\text { Composition } \\
\text { of the } \\
\text { complex }\end{array}$} & \multirow{2}{*}{$\begin{array}{l}\text { Stability } \\
\text { Constant }\end{array}$} & \multirow{2}{*}{$\begin{array}{l}\text { Molar } \\
\text { absorptivity }\end{array}$} & \multirow{2}{*}{$\begin{array}{l}\text { Sandell's } \\
\text { sensitivity }\end{array}$} & \multirow{2}{*}{$\begin{array}{l}\text { Range of } \\
\text { determination } \\
(\mu \mathrm{g} / \mathrm{ml})\end{array}$} & \multicolumn{2}{|c|}{$\begin{array}{l}\text { Remarks } \\
\text { Statistical data }\end{array}$} \\
\hline & & & & & & & & & S.D. & $\begin{array}{l}\text { R.S.D } \\
\text { (\%) }\end{array}$ \\
\hline $\mathrm{Fe}$ (II) & 9 & Yellow & 355 & $1: 1$ & $\begin{array}{c}2.343 \mathrm{x} \\
10^{5}\end{array}$ & $\begin{array}{c}3.83 \times 10^{4} \text { lit } \\
\mathrm{mol}^{-1} \mathrm{~cm}^{-1}\end{array}$ & 0.002929 & $0.540-5.396$ & 0.001194 & 0.138 \\
\hline $\mathrm{V}(\mathrm{V})$ & 7 & $\begin{array}{l}\text { Greenish } \\
\text { Yellow }\end{array}$ & 356 & $1: 1$ & $\begin{array}{c}2.412 \mathrm{x} \\
10^{7}\end{array}$ & $\begin{array}{l}2.65 \times 10^{4} \text { lit } \\
\mathrm{mol}^{-1} \mathrm{~cm}^{-1}\end{array}$ & 0.008262 & $0.508-5.084$ & 0.002649 & 0.579 \\
\hline $\mathrm{Ga}$ (III) & 6 & $\begin{array}{l}\text { Greenish } \\
\text { Yellow }\end{array}$ & 362 & $1: 1$ & $\begin{array}{c}6.204 \mathrm{x} \\
10^{6}\end{array}$ & $\begin{array}{l}3.17 \times 10^{4} \text { lit } \\
\mathrm{mol}^{-1} \mathrm{~cm}^{-1}\end{array}$ & 0.002002 & $0.203-2.033$ & 0.0149 & 2.899 \\
\hline $\mathrm{Ni}$ (II) & 9 & Brown & 365 & $1: 1$ & $\begin{array}{c}3.21 \mathrm{x} \\
10^{6}\end{array}$ & $\begin{array}{l}4.08 \times 10^{4} \text { lit } \\
\mathrm{mol}^{-1} \mathrm{~cm}^{-1}\end{array}$ & 0.00219 & $0.188-1.886$ & 0.478 & 0.00182 \\
\hline $\begin{array}{l}\mathrm{Ru} \\
\text { (III) }\end{array}$ & 10 & Yellow & 363 & $1: 2$ & $\begin{array}{c}8.620 \mathrm{x} \\
10^{6}\end{array}$ & $\begin{array}{c}3.45 \times 10^{4} \text { lit } \\
\mathrm{mol}^{-1} \mathrm{~cm}^{-1}\end{array}$ & 0.005024 & $0.470-4.695$ & 0.003349 & 0.589 \\
\hline $\begin{array}{c}\mathrm{Al} \\
\text { (III) }\end{array}$ & 8 & $\begin{array}{l}\text { Golden } \\
\text { Yellow }\end{array}$ & 355 & $1: 2$ & $\begin{array}{c}1.01 \mathrm{x} \\
10^{5}\end{array}$ & $\begin{array}{c}2.69 \times 10^{4} \text { lit } \\
\mathrm{mol}^{-1} \mathrm{~cm}^{-1}\end{array}$ & 0.007526 & $0.785-7.588$ & 0.00332 & 0.348 \\
\hline $\mathrm{Hg}$ (II) & 6 & $\begin{array}{c}\text { Pale } \\
\text { Yellow }\end{array}$ & 364 & $1: 1$ & $\begin{array}{c}6.24 \mathrm{x} \\
10^{7}\end{array}$ & $\begin{array}{c}5.06 \times 10^{4} \text { lit } \\
\mathrm{mol}^{-1} \mathrm{~cm}^{-1}\end{array}$ & 0.003240 & $0.942-9.426$ & 0.00174 & 0.302 \\
\hline
\end{tabular}

\section{Recommended Procedures}

(a). Determination of aluminium

An aliquot of the solution containing $0.48-4.56 \mu \mathrm{g} / \mathrm{mL}$ (ppm) of $\mathrm{Al}(\mathrm{III}), 10 \mathrm{ml}$ of NH4cl-NH4OH buffer solution (pH 8.0), $3 \mathrm{ml}$ of DMF and $1 \mathrm{ml}$ o f $0.01 \mathrm{M}$ DAMINH were combined in a $25 \mathrm{ml}$ volumetric flasks and the resulting solution was diluted to the mark with distilled water. The absorbance of the solution was read at $355 \mathrm{~nm}$ against reagent blank. The measured absorbance is used to compute the amount of aluminium from predetermined calibration curve.

\section{(b). Determination of gallium}

An aliquot of the solution containing $0.2032-2.033 \mu \mathrm{g} / \mathrm{mL}$ (ppm) of Ga(III), $10 \mathrm{ml}$ of NH4clNH4OH buffer solution ( $\mathrm{pH} 6.0), 3 \mathrm{ml}$ of DMF and $1 \mathrm{ml}$ of $0.01 \mathrm{M}$ DAMINH were combined in a $25 \mathrm{ml}$ volumetric flasks and the resulting solution was diluted to the mark with distilled water. The absorbance of the solution was read at $362 \mathrm{~nm}$ against reagent blank. The measured absorbance is used to compute the amount of aluminium from predetermined calibration curve. 
Simultaneous Second Order Derivative Spectrophotometric Determination Of Gallium(III) And (c). Simultaneous determination of Aluminium and Gallium

A known aliquot of a alloy containing $0.632-5.85 \mu \mathrm{g} / \mathrm{mL} \mathrm{Al(III)} \mathrm{and} 0.743-7.543 \mu \mathrm{g} / \mathrm{mL}$ of $\mathrm{Ga}(\mathrm{III}), 3 \mathrm{ml}$ of DMF and $1 \mathrm{ml}$ of $0.01 \mathrm{M}$ DAMINH were combined in a 25 volumetric flask and the resulting solution was diluted to the mark with distilled water. The absorbance was measured at $355 \mathrm{~nm}$ and $362 \mathrm{~nm}$ against reagent blank and the amounts of Aluminium (III) and Gallium (III) were respectively determined by solving the simultaneous equations.

\section{Results And Discussion}

DiacetylmonoximeIsonicotinoylHydrazone is a new chromogenic reagent was not used for spectrophotometric simultaneous determination of $\mathrm{Ga}$ and $\mathrm{Al}$ so far. DAMINH reagent can easily prepared like any other Schiff base reagent. The reactions of some important metal ions with DAMINH are summarized in table1. The color reactions are mainly due to the complex formation of DAMINH with certain metal ions like $\mathrm{Ni}(\mathrm{II}), \mathrm{Al}(\mathrm{III}), \mathrm{Ru}(\mathrm{III}), \mathrm{Fe}(\mathrm{II}), \mathrm{V}(\mathrm{V}), \mathrm{Hg}(\mathrm{II}), \mathrm{Ga}(\mathrm{III})$ to give intense color complexes

\section{Simultaneous determination of $\mathrm{Ga}$ (III) and $\mathrm{Al}(\mathrm{III})$ in synthetic mixture}

The simultaneous spectrophotometric determination of aluminium(III) and gallium(III) in alloys and biological samples was carried out by employing the recommended procedure and the results are presented in the table

Determination of aluminium (III) and gallium (III)

Aluminium(III) and gallium (III) reacts with DAMINH neutral medium to give yellow colored complex. The color reactions are instantaneous even at room temperature at $\mathrm{pH} 7$ range. The absorbents of yellow colored complexes remains stable for more than 10 hours in both cases. The maximum color intensity is observed at in the $\mathrm{pH}$ 5-6 and 7-8 range for Ga-DAMINH and Al-DAMINH complexes respectively. A 10 fold molar excess of reagent is sufficient for full color development in both systems. Addition of excess reagent has no adverse effect on the absorbance. The order of addition of metal ions, buffer, reagent and triton X-100 solutions has no adverse effect on the absorbance of complexes. Important analytical characteristics of AlDAMINH and Ga-DAMINH complexes are computed in table2.

Table 2: Important analytical characteristics of AI-DAMINH and Ga-DAMINH complexes

\begin{tabular}{|c|c|c|}
\hline \multirow[b]{2}{*}{ Characteristics } & \multicolumn{2}{|c|}{$\begin{array}{r}\text { Resu } \\
\text { Its }\end{array}$} \\
\hline & $\begin{array}{l}\text { Al(III)- } \\
\text { DAMINH }\end{array}$ & $\begin{array}{r}\text { Ga(III)- } \\
\text { DAMINH }\end{array}$ \\
\hline $\begin{array}{l}\lambda_{\max }(\mathrm{nm}) \\
\text { Mole of reagent required per mole of metal } \\
\text { ion } \\
\text { for full colour development }\end{array}$ & $\begin{array}{l}355 \\
5 \text { - folds }\end{array}$ & $\begin{array}{l}362 \\
10-\text { folds }\end{array}$ \\
\hline Detection limit $(\mu \mathrm{g} / \mathrm{mL})$ & 0.0735 & 0.0934 \\
\hline Limit of Quantization $(\mu \mathrm{g} / \mathrm{mL})$ & 0.1454 & 0.1592 \\
\hline Molar absorptivity $\left(\mathrm{L} \cdot \mathrm{mol}^{-1} \cdot \mathrm{cm}^{-1}\right)$ & $2.69 \times 10^{4}$ & $3.17 \times 10^{4}$ \\
\hline Sandell's sensitivity $\left(\mu \mathrm{g} . \mathrm{cm}^{-2}\right)$ & 0.00745 & 0.002002 \\
\hline Beer's law validity range $(\mu \mathrm{g} / \mathrm{mL})$ & $0.828-8.0$ & $0.92-9.2$ \\
\hline Optimum concentration range $(\mu \mathrm{g} / \mathrm{mL})$ & $0.392-2.452$ & $0.5352-4.09$ \\
\hline Slope (b) & 0.224 & 0.195 \\
\hline Intercept (a) & 0.045 & 0.048 \\
\hline Correlation coefficient & 0.9891 & 0.8240 \\
\hline Specific absorptivity $\left(\mathrm{ml}^{\left.-\mathrm{g}^{-1} \cdot \mathrm{cm}^{-1}\right)}\right.$ & 2.08 & 2.45 \\
\hline Relative standard deviation (\%) & 0.346 & 2.899 \\
\hline $\begin{array}{l}\text { Composition of complex (M:L) obtained in } \\
\text { Job's } \\
\text { and mole ratio method }\end{array}$ & 1: 1 & 1: 1 \\
\hline
\end{tabular}

The direct and first order spectra of solutions of $\mathrm{Al}(\mathrm{III})$-DAMINH and $\mathrm{Ga}$ (III)-DAMINH complexes in an aqueous neutral buffer medium $(\mathrm{pH}=7)$ are shown in Figure 2. The absorption spectra overlap considerably and therefore direct and first order spectrophotometeric determination of one metal in the presence of the other is not possible. 


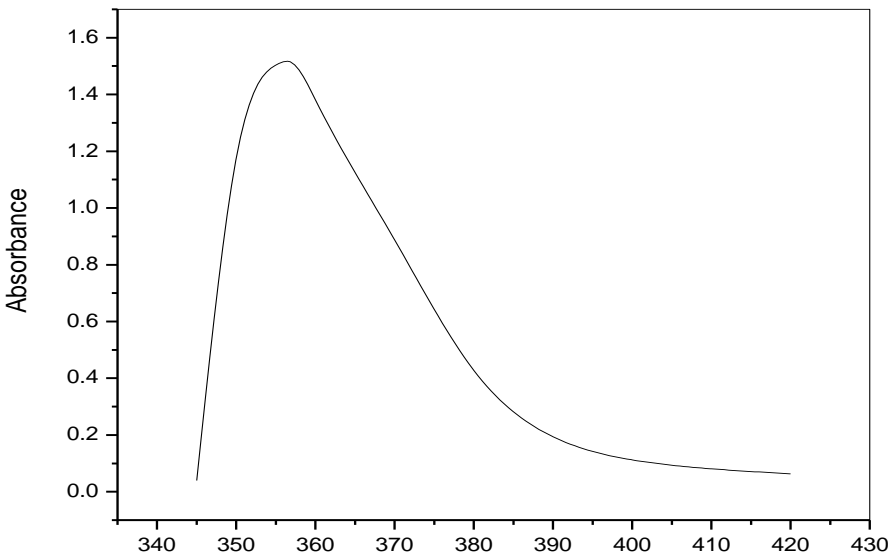

Fig: 1 Zero order spectrum of Al(IIII) + Ga(III) in the presence of DAMINH

$\begin{array}{lll}{[\mathrm{Al}(\mathrm{III})]} & = & 4 \times 10^{-5} \mathrm{M}, \\ {[\mathrm{Ga}(\mathrm{III})]} & = & 1.6 \times 10^{-5} \mathrm{M} ; \\ {[\mathrm{DAMINH}]} & = & 5.6 \times 10^{-4} \mathrm{M} ; \\ \mathrm{pH}=7.0 & & \end{array}$

Derivative spectrophotometric determination of aluminium(III) and gallium(III)

Second order derivative spectrophotometric is useful technique for simultaneous aluminium(III) and gallium(III) because it decreases the interference of adverse ions i.e., increase the tolerance limit value of foreign ions and may be advantageously used for the determination of metal ins having overlapping spectra. The main reason why the interest in derivative spectra is due to simplicity, relatively quick, easy realization and increased analysis of minor components. The recommended derivative processor was employed for the simultaneous determination of aluminium(III) and gallium(III).

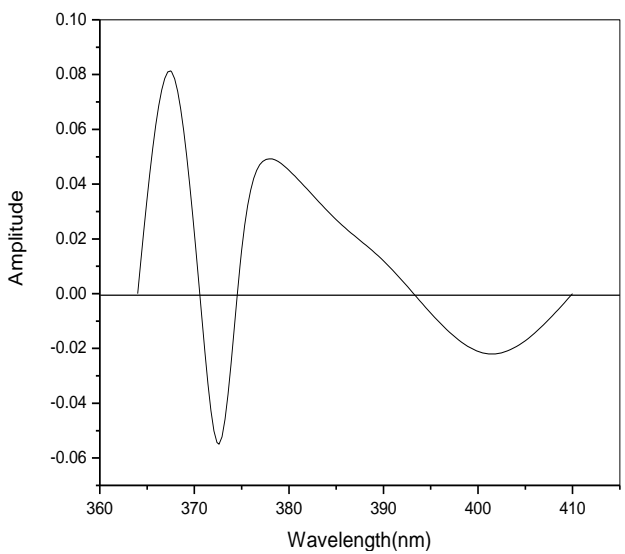

Fig:2 Typical second order spectrum of $\mathrm{Al}(\mathrm{III})+\mathrm{Ga}(\mathrm{III})$ in the presence of DAMINH

$\begin{array}{lll}{[\mathrm{Al}(\mathrm{III})]} & = & 4 \times 10^{-5} \mathrm{M}, \\ {[\mathrm{Ga}(\mathrm{III})]} & = & 1.6 \times 10^{-5} \mathrm{M} ; \\ {[\mathrm{DAMINH}]} & = & 5.6 \times 10^{-4} \mathrm{M} ; \\ \mathrm{pH}=7.0 & & \end{array}$

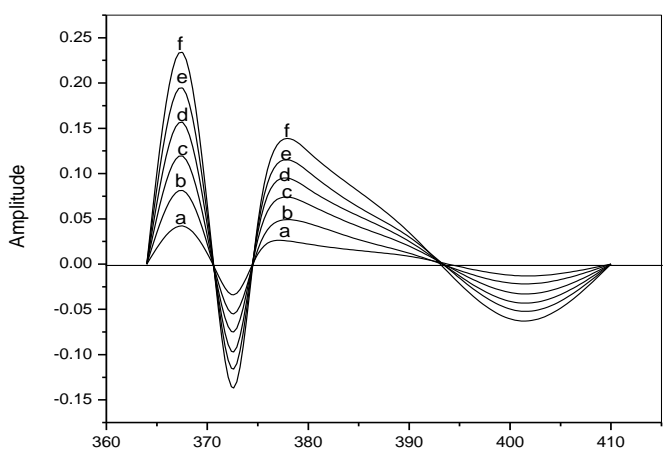

Fig: 3.13.5 Second order spectrum of Âl(III) $+\mathrm{Ga}(\mathrm{III})$ in the presence of DAMINH 
Simultaneous Second Order Derivative Spectrophotometric Determination Of Gallium(III) And

$\begin{array}{lll}{[\mathrm{Al}(\mathrm{III})]} & = & 4.0 \times 10^{-5} \mathrm{M} ; \\ {[\mathrm{Ga}(\mathrm{III})]} & = & 1.6 \times 10^{-5} \mathrm{M} \\ \text { [DAMINH] } & 5.6 \times 10^{-4} \mathrm{M} ; \mathrm{pH}=7.0 \\ \text { a) } \quad 0.5 \mathrm{ml} \text { of } \mathrm{Al}(\mathrm{III}) & \text { and } \mathrm{Ga}(\mathrm{III}) \text { each } \\ \text { b) } & 1.0 \mathrm{ml} & , \\ \text { c) } & 1.5 \mathrm{ml} & ", \\ \text { d) } & 2.0 \mathrm{ml} & , \\ \text { e) } & 2.5 \mathrm{ml} & , \\ \text { f) } & 3.0 \mathrm{ml} & ,\end{array}$

\section{Interference}

The selectivity of the derivative methods was tested by studying the effect of foreign ions which brings about change the amplitude by $+2 \%$ was taken as the tolerance limit. Interference of diverse ions which often accompany with $\mathrm{Al}(\mathrm{III})$ and $\mathrm{Ga}(\mathrm{III})$ has been studied in the determination of $1.3798 \mu \mathrm{g} / \mathrm{mL}$ of $\mathrm{Al}$ (III) and 3.042 $\mu \mathrm{g} / \mathrm{mL}$ of $\mathrm{Ga}(\mathrm{III})$. The results are computed in table 3 .

Table 3. Tolerance limit of foreign ions in the determination of $3.042 \mu \mathrm{g} / \mathrm{mL} \mathrm{Ga(III)} \mathrm{and} 1.3798 \mu \mathrm{g} / \mathrm{mL}$ of $\mathrm{Al}(\mathrm{III})$.

\begin{tabular}{|l|r|l|r|}
\hline Foreign ion & $\begin{array}{c}\text { Tolerance } \\
\text { limit } \\
(\mu \mathrm{g} / \mathrm{ml})\end{array}$ & Foreign ion & $\begin{array}{c}\text { Tolerance } \\
\text { limit } \\
(\mu \mathrm{g} / \mathrm{ml})\end{array}$ \\
\hline Fluoride & 217.12 & $\mathrm{Al}(\mathrm{III})$ & 24.1 \\
\hline Chloride & 176.25 & $\mathrm{~Pb}$ (II) & 1657.6 \\
\hline IDdide & 507.60 & $\mathrm{~W}$ (VI) & 73.54 \\
\hline Nitrate & 992.04 & $\mathrm{Co}$ (II) & 7.04 \\
\hline Acetate & 188.94 & $\mathrm{Se}(\mathrm{II})$ & 30.08 \\
\hline Oxalate & 20.0 & $\mathrm{Mn}(\mathrm{II})$ & 39.96 \\
\hline EDTA & 78.0 & $\mathrm{La}(\mathrm{III})$ & 123.1 \\
\hline thiosulphate & 19.72 & $\mathrm{Zn}$ (II) & 261.6 \\
\hline & & $\mathrm{Ru}(\mathrm{II})$ & 26.95 \\
\hline & & $\mathrm{Ni}$ (II) & 78.27 \\
\hline & & $\mathrm{Mo}(\mathrm{VI})$ & 5.69 \\
\hline & & $\mathrm{Hg}$ (II) & 5.29 \\
\hline & & $\mathrm{Pd}(\mathrm{II})$ & 0.59 \\
\hline & & $\mathrm{Ag}(\mathrm{I})$ & 1.68 \\
\hline & & $\mathrm{Mg}(\mathrm{II})$ & 1.793 \\
\hline & & $\mathrm{V}(\mathrm{IV})$ & 21.4 \\
\hline & & $\mathrm{V}(\mathrm{V})$ & 23.1 \\
\hline
\end{tabular}

\begin{tabular}{|c|c|c|c|}
\hline \multicolumn{4}{|c|}{$\begin{array}{l}\text { Al(III)- } \\
\text { DAMINH }\end{array}$} \\
\hline Foreign ion & $\begin{array}{c}\text { Tolerance limit } \\
(\mu \mathrm{g} / \mathrm{ml}) \\
\end{array}$ & $\begin{array}{c}\text { Foreign } \\
\text { ion } \\
\end{array}$ & $\begin{array}{c}\text { Tolerance limit } \\
(\mu \mathrm{g} / \mathrm{ml})\end{array}$ \\
\hline Fluoride & 20.54 & $\mathrm{U}(\mathrm{VI})$ & 82.80 \\
\hline Chloride & 54.62 & $\mathrm{Ru}$ (III) & 13.26 \\
\hline iodide & 253.8 & $\mathrm{~W}(\mathrm{VI})$ & 63.95 \\
\hline nitrate & 130.53 & Co (II) & 0.31 \\
\hline acetate & 43.7 & Mo (VI) & 19.2 \\
\hline oxalate & 8.85 & $\mathrm{Se}$ (IV) & 5.45 \\
\hline EDTA & 1667 & $\mathrm{Pd}$ (II) & 0.12 \\
\hline \multirow[t]{8}{*}{ thiosulphate } & 15.5 & $\mathrm{Mg}$ (II) & 32.41 \\
\hline & & $\mathrm{Cu}$ (II) & 0.45 \\
\hline & & $\mathrm{Sn}$ (II) & 14.84 \\
\hline & & $\mathrm{Ni}$ (II) & 0.612 \\
\hline & & $\mathrm{Zr}$ (IV) & 10.73 \\
\hline & & $\mathrm{Sr}$ (II) & 12.75 \\
\hline & & $\mathrm{La}$ (III) & 52.91 \\
\hline & & $\mathrm{Ti}$ (IV) & 6.96 \\
\hline & & $\mathrm{Al}$ (III) & 13.49 \\
\hline & & Th (IV) & 64.01 \\
\hline & & $\mathrm{Cd}$ (II) & 0.804 \\
\hline & & $\mathrm{Cr}(\mathrm{Vl})$ & 5.19 \\
\hline
\end{tabular}

\section{Applications}

The validity of the proposed method was tested by analyzing alloys sample and biological samples containing $\mathrm{Al}(\mathrm{III})$ and $\mathrm{Ga}$ (III). Satisfactory results were obtained for the recovery of both the metals indicating that the proposed method is effective for their simultaneous determination

\section{Analysis of Alloys and Biological samples:}

$1 \mathrm{gm}$ of alloy sample was digested in $10 \mathrm{~mL}$ of aqua-regia by worming and the solution was evaporated to dryness. The residue was dissolved in $20 \mathrm{~mL}$ of diluted $\mathrm{HCl}$ and resulting solution concentrated to $10.0 \mathrm{~mL}$, diluted to $100 \mathrm{~mL}$ with doubly distilled water, filtered and made up to the mark in a $250-\mathrm{mL}$ volumetric flask.

The simultaneous second order derivative spectrophotometric determination of $\mathrm{Al}(\mathrm{III})$ and $\mathrm{Ga}(\mathrm{III})$ in the biological samples, alloy samples were carried out by employing the recommended procedure. A known aliquot of the sample solution was taken in a $25-\mathrm{mL}$ volumetric flask containing $10 \mathrm{~mL}$ buffer $(\mathrm{pH}=7), 1.0 \mathrm{ml}$ of Triton X-100 (5\%) solution and $1.0 \mathrm{~mL}$ of DAMINH reagent $(0.01 \mathrm{M})$ solutions. The contents in the flask were made up to the mark with doubly distilled water. The second derivative amplitudes of the reaction 
Simultaneous Second Order Derivative Spectrophotometric Determination Of Gallium(III) And mixture were measured at $367 \mathrm{~nm}$ and $377 \mathrm{~nm}$. The amount of aluminium(III) was computed from the predetermined calibration plot at $367 \mathrm{~nm}$. Similarly, the amount of gallium(III) was deduced from the predetermined calibration plot at $377 \mathrm{~nm}$. The results are computed in Table 4 and Table 5 respectively.

Table 4: Simultaneous determination of $\mathrm{Al}(\mathrm{III})$ and $\mathrm{Ga}(\mathrm{III})$ in alloys

\begin{tabular}{|c|c|c|c|c|c|}
\hline \multicolumn{2}{|c|}{ Amount taken $(\mu \mathrm{g} \mathrm{mL}-1)$} & \multicolumn{2}{c|}{$\begin{array}{c}\text { Amount found* }(\mu \mathrm{g} \mathrm{mL}-1) \\
(\% \text { of recovery })\end{array}$} & \multicolumn{2}{c|}{ Relative error (\%) } \\
\hline $\mathrm{Al}(\mathrm{III})$ & $\mathrm{Ga}(\mathrm{III})$ & $\mathrm{Al}(\mathrm{III})$ & $\mathrm{Ga}(\mathrm{III})$ & $\mathrm{Al}(\mathrm{III})$ & $\mathrm{Ga}(\mathrm{III})$ \\
\hline 0.050 & 0.432 & $0.049(98.2)$ & $0.425(99)$ & -1.84 & -1.10 \\
\hline 0.100 & 0.432 & $0.101(101.6)$ & $0.428(99.6)$ & +1.71 & -0.54 \\
\hline 0.150 & 0.432 & $0.148(99.6)$ & $0.439(101.4)$ & -0.60 & +1.30 \\
\hline 0.200 & 0.432 & $0.197(98.8)$ & $0.430(99.7)$ & -1.37 & -0.36 \\
\hline 0.250 & 0.432 & $0.248(99.4)$ & $0.428(99.6)$ & -0.72 & -1.49 \\
\hline 0.300 & 0.432 & $0.303(101.2)$ & $0.441(101.9)$ & +1.22 & +1.68 \\
\hline 0.100 & 0.216 & $0.101(101.6)$ & $0.215(99.5)$ & +0.91 & -1.49 \\
\hline 0.100 & 0.432 & $0.098(98.4)$ & $0.430(98.6)$ & -1.83 & -1.30 \\
\hline 0.100 & 0.648 & $0.099(99.2)$ & $0.646(99.7)$ & -0.91 & -0.49 \\
\hline 0.100 & 0.864 & $0.100(100)$ & $0.866(101)$ & 0.00 & +0.92 \\
\hline 0.100 & 1.080 & $0.101(101.96)$ & $1.075(99.4)$ & +0.92 & +0.65 \\
\hline 0.100 & 1.296 & $0.100(100)$ & $1.292(99.4)$ & 0.00 & -0.42 \\
\hline
\end{tabular}

Table 5: Simultaneous determination of $\mathrm{Al}(\mathrm{III})$ and $\mathrm{Ga}(\mathrm{III})$ in biological samples

\begin{tabular}{|c|c|c|c|c|}
\hline \multirow{2}{*}{ Sample } & \multicolumn{2}{|c|}{$\mathrm{Ga}(\mathrm{III})(\mu \mathrm{g}$ mL-1) } & \multicolumn{2}{c|}{$\mathrm{Al}(\mathrm{III})(\mu \mathrm{g}$ mL-1) } \\
\cline { 2 - 5 } & Added & Found* & Added & Found \\
\hline Blood serum 1 & 0.250 & 0.254 & 0.135 & 0.133 \\
\hline Blood serum 2 & 0.620 & 0.622 & 0.075 & 0.078 \\
\hline Blood serum 3 & 1.250 & 1.254 & 0.230 & 0.233 \\
\hline Kidney & 0.980 & 0.986 & 0.180 & 0.179 \\
\hline Brain & 1.46 & 1.47 & 0.325 & 0.324 \\
\hline \multicolumn{4}{|c}{ *average of four determinations } \\
\hline
\end{tabular}

\section{Conclusions}

DiacetylmonoximeIsonicotinoylHydrazone is a versatile chromogenic reagent used for the simultaneous determination of $\mathrm{Ga}(\mathrm{III})$ and $\mathrm{Al}(\mathrm{III})$ in neutral medium in microgram quantities. The present second order derivative spectrophotometric method is simple, rapid, sensitive and selective and do not involve heating or filtration or separation. Foreign ions do not interfere in the determinations. The method precise and accurate determinations can be made. Triton- $X$ increases the stability of the complex. Hence simultaneous determination of $\mathrm{Ga}(\mathrm{III})$ and $\mathrm{Al}(\mathrm{III})$ can carried out by using DAMINH by the present method.

\section{References}

[1]. Clark R E D, The colorimetric determination of tin by means of Toluene -3:4-dithiol (Dithiol). Analyst 1937, 62 , 661.

[2]. Katyal M and Dutt Y, Analytical applications of hydrazones. Talanta 1975, 22, $151-166$.

[3]. Jeewoth T, Li Kam Wah H, Bhowon M G, Ghoorohoo D and Babooram K, Synthesis and anti bacterial/catalytical properties of Schiff bases and Schiff base metal complexes derived from 2,3-diaminopyridine. Synthesis and Reactivity in Inorganic and Metal Organic Chemistry 2000, 30, 1023-1038.

[4]. RB Singh, P Jain \& RP Singh. Talanta 1982; 29 (2): 77.

[5]. AM Wahbi, H Abdine \& S Balaiah. J Assoc Off Anal Chem 1977; 60: 1175.

[6]. M Bedair, MA Korany, EI-Yazbi. Sci F A Pharma 1986; 54: 31.

[7]. MA Korany, AM Wahbi, MA Elasayed \& S Mandour. Anal Lett 1984; 17: 1373.

[8]. K Hussain Reddy, KB Chandrasekhar. Indian J Chem 2001; 40 A: 727.

[9]. KB Chandrasekhark, KH Reddy \& T Sreenivasula Reddy. J Indian Chem Soc 2003; 80: 930.

[10]. KB Chandrasekhar \& KH Reddy. Indian J Chem 2002; 41 (A): 1643.

[11]. V Kiran Kumar, M Rameswara Rao, KB Chandrasekhar \& N Devanna. Asian J Chem 2008; 20 (3): 2197. 